\title{
ДИНАМИКА МИРОВОГО ПРОИЗВОДСТВА И ТОВАРНЫХ ПОТОКОВ НИОБИЕВОГО СЫРЬЯ
}

\author{
Боярко Григорий Юрьевич, \\ gub@tpu.ru \\ Национальный исследовательский Томский политехнический университет, \\ Россия, 634050, г. Томск, пр. Ленина, 30.
}

\begin{abstract}
Актуальность работы обусловлена необходимостью изучения проблем монопольного мирового рынка ниобия. Цель: изучение динамики мировых товарных потоков (производства, импорта, экспорта, потребления) ниобиевых продуктов (ниобиевых концентратов и феррониобия); выработка предложений по снижению уровня монополизации предложения ниобиевого сырья.

Методы: статистический, графический, логический.

Результаты. Мировой рынок ниобиевых продуктов является исключительно монополизированным с абсолютным доминированием бразильской компании Companhia Brazileira de Metalurgia e Mineraçã (CВMM). Разработка крупнейшего в мире месторождения ниобия Араша с высококачественными и технологичными пирохлоровыми рудами и отлаженное производство позволяют СВММ удерживать монопольную позицию. Учтенных мировых ресурсов ниобия $\left(44,7\right.$ млн т $\mathrm{Nb}_{2} \mathrm{O}_{5}$ ) достаточно более чем на 50 лет растущего потребления ниобиевых продуктов. 63 \% мировых ресурсов ниобия приходится на Бразилию. Мировой сбыт феррониобия вырос с 25 тыс. т в 1996 г. до 105 тыс. т в 2014 г., темпы прироста +8,7%/год. В международной торговле находится более 95 \% от производимого в мире феррониобия. На экспорт Бразилия поставляет 69,5-86,6 тыс. т/год, Канада 6,1-10,7 тыс. т/год. Главными импортерами феррониобия являются США, Япония, Германия, Китай, Южная Корея, Италия, Бельгия, Франция и Россия. Выросли объемы импорта феррониобия в Китай (до 16,8 тыс. т в 2017 г., прирост +20,0%/год), в США, Россию и Южную Корею, сократились в Испанию. Среднемировая цена феррониобия во времени выросла с 8,6 $\$$ США/Кг в 2004 г. до 26,3 \$ США/кг в 2012 г., после чего начала снижаться вплоть до 19,6 \$ США/кг в 2017 г. Средние цены импорта ниже среднемировой наблюдаются для Китая $(-1,5 \%$ отн.) и России $(-19,5 \%$ отн.). Выше среднемировой цены феррониобия средние цены на импорт (+0,6...6,2% отн.) в Японию, Францию, Италию, Бельгию, США, Германию, Британию. Значительно выше среднемировых цены импорта феррониобия в Индию, составлявшие в 2006-2017 гг. +39...65 \% отн. Мировое потребление феррониобия во времени увеличивается, имея прирост объемов $+9,1$ \%/год, что значительно опережает прирост производства стали $(+4,3$ \%/год) и других ферросплавов (+3..6\%/год). Растет мировое удельное потребление феррониобия на 1 т стальной продукции - с 28 г/т в 1996 г. до 63 г/т в 2017 г. По абсолютным объемам потребления феррониобия наибольшие темпы прироста приходятся на Китай - с 0,9 тыс. т в 1999 г. до 16,8 тыс. т в 2017 г. (темп прироста +25,2%/год). Высокие темпы прироста абсолютного потребления также в Южной Корее, России, Индии и Бельгии. Превышает среднемировой уровень удельного потребления феррониобия (2017г.) в Бельгии (250 г/т), Германии (155 г/т), США (111 г/т), Южной Кореи (106 г/т), Франции (97 г/T), Японии (85 г/T), Италии (84 г/T), Британии (84 г/T) и России (73 г/T). Компания СвММ ведет активную ценовую политику, препятствующую появлению в других странах новых проектов добычи ниобия. Второй проблемой освоения большинства ниобиевых месторождений является многокомпонентность их состава, которая несет риски дисбаланса реализации получаемых товарных продуктов. Наиболее интересен проект разработки Томторского ниобий-редкоземельного месторождения в России, при определенных условиях возможно осуществление проектов Элк-Крик в США, Гхурауях в Саудовской Аравии, Бонга в Намибии, Сукулу в Уганде, Мотзфельд в Гренландии, Большезиминское в России.
\end{abstract}

Ключевые слова:

Ниобиевое сырье, Бразилия, монополия, феррониобий, производство, экспорт, импорт, потребление, ценообразование.

\section{Введение}

Ниобий - металл, обладающий высокой пластичностью, коррозионной стойкостью, хорошей свариваемостью и малым сечением захвата тепловых нейтронов. Он является микролигирующей добавкой (в виде феррониобия) в составе сплавов, обладающих высокой прочностью и значительной пластичностью, жаро-, морозо- и коррозионностойкостью $[1,2]$.

Мировой рынок ниобиевых продуктов своеобразен наличием значительных сырьевых ресурсов в множестве крупных месторождений, разбросанных по всему миру и при этом абсолютным доминированием на мировом рынке продаж феррониобия одной бразильской компании Companhia Brazileira de Metalurgia e Mineraçã (CBMM), осуществившей 86 \% его мирового накопленного производства. Потребности в феррониобии выросли за последние 20 лет в пять раз, многократно опередив прирост востребованности других ферросплавов.
Ниобий признан критическим материалом для экономики США [3], Европейского Союза [4], России [5] и других стран.

Геологические комплексы, в которых находятся месторождения ниобия, представлены магматическими карбонатитами, редкометалльными пегматитами, щелочными гранитами и сиенитами. Все эти комплексы представляют так называемую геологическую экзотику, и их изучение всегда весьма подробно. Поэтому поиски редкометалльных месторождений, в частности ниобия, весьма эффективны, особенно с применением геохимических методов. Основными минералами ниобия являются: пирохлор (40-80\% $\mathrm{Nb}_{2} \mathrm{O}_{5}$, в карбонатитах), колулбит-танталит (50-78\% $\mathrm{Nb}_{2} \mathrm{O}_{5}$, в пегматитах, щелочных гранитах и сиенитах), лопаpum (6-8 \% $\mathrm{Nb}_{2} \mathrm{O}_{5}$, в щелочных сиенитах). Кроме этого, ниобий извлекается из шлаков переработки оловянных концентратов. Положительным фактором для освоения ниобиевых месторождений в 
карбонатитовых массивах является то, что в результате экзогенного выветривания легко разрушаемых карбонатов происходит накопление свободных зерен пирохлора, а сами руды представляют собой технологичный для обогащения рыхлый материал. Существенным негативным фактором для многих ниобиевых залежей является многокомпонентность получаемой продукции (тантал, редкоземельные металлы, литий, цирконий, титан, фосфор и др.), что усложняет производство переработки руд и повышает риски освоения таких месторождений.

\section{Методы исследований}

$\mathrm{C}$ целью изучения мирового рынка ниобиевых продуктов были обработаны наиболее полные данные по мировой добыче ниобиевого сырья за 1950-2017 гг., по производству феррониобия за 2004-2017 гг., а также по мировым ценам на различные ниобиевые продукты. Источники информации: бюллетени и обзоры Геологической службы США [6] и Британии [7], Государственные доклады Министерства природных ресурсов России [5], базы данных Федеральной таможенной службы России [8] и Госкомстата России [9], обзоры информационных центров $[10,11]$. Ввиду различий в представлении информации по единицам измерений объемов добычи ниобиевых руд и концентратов и производства феррониобия ферросплавов (торговых фунтов, коротких, длинных и метрических тонн, веса сырой руды, массы пересчетов на $100 \%$ учтенных $\mathrm{Nb}$ и $\mathrm{Nb}_{2} \mathrm{O}_{5}$ ), а также изменчивости качества реализуемого ниобиевого концентрата, его объемы приведены к метрическим тоннам в пересчете на $100 \% \mathrm{Nb}$. Аналогично цены на ниобиевые продукты приведены к стоимости их метрической тонны. Учет ресурсов ниобиевых руд и концентратов приводится к метрическим тоннам содержания в них $100 \%$ учтенного $\mathrm{Nb}_{2} \mathrm{O}_{5}$. Информация по ниобиевым продуктам доступна с большими лакунами, в частности, с 1981 г. бразильская компания СВММ не публикует данных по отпускным ценам на ниобиевые товары. Аналогично нет данных по ценам на канадские ниобиевые продукты с 1989 г. Цены на ниобиевый концентрат и феррониобий определялись косвенно - по объемам и стоимости импортных потоков этих товарных продуктов.

\section{Источники (добыча) ниобиевого сырья}

Долонопольный период развития ниобиевого рынка. В 40-50-е гг. ХХ в. мировые потребности в ниобиевом сырье для производства специальных сплавов сталей составляли всего $0,3-1,5$ тыс. т и удовлетворялись поставками из стран - переменных лидеров добычи - Юго-Западной Африки (ныне Намибии), Нигерии, Бразилии, а также Канады, Бельгийского Конго (ныне Республики Конго), Норвегии и других стран (рис. 1). Ниобиевое сырье извлекалось в виде колумбит-танталитовых концентратов при разработке оловоносных пегматитов месторождения Юс-Тин в Юго-Западной Афри- ке (ныне Намибии), месторождений Маноно и Маниема в Бельгийском Конго (ныне Демократической Республики Конго) и месторождения Фонтаинхас в Португалии, попутного колумбита из оловянных россыпей Семилинга в штате Кедах в Малайзии, пирохлоровых концентратов из щелочных гранитов месторождения Каффо в Нигерии, а также из карбонатитов месторождений Сёвё в Норвегии, Ока в Канаде, Араша в Бразилии и Кайзершталь в Западной Германии.

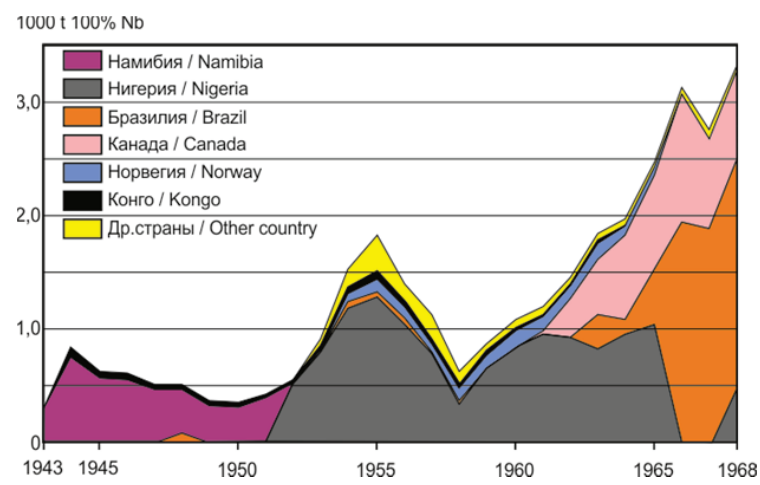

Pис. 1. Динамика мирового производства ниобиевого сырья в до монопольный период за 1943-1968 г2. Составлено по данным Геологической службы США [6] и Британии [7]

Fig. 1. Dynamics of world production of niobium raw materials in premonopoly period 1943-1968. Compiled according the data of the U.S. Geological Survey [6] and Britain Geological Survey [7]

Монополизация мирового ниобиевого рынка. Начиная с 1967 г. происходит рост мирового потребления ниобия с 2,3 тыс. т/год вплоть до 15 тыс. т в 1980 г. (рис. 2). Спрос перекрывается наращиванием добывающих мощностей на открытом в 1953 г. крупнейшем в мире ниобиевом месторождении Араша в Бразилии [12] (рис. 4), разрабатываемом оператором СВММ, при этом доля этой компании в мировых поставках выросла с 0,5 \% в 1962 г. до 85 \% в 1980 г. Кроме бразильских поставок наращиваются предложения канадской компанией St. Lawrence Columbium and Metals Corp. (StLC\&MC) ниобия, добытого на месторождении Ока - с 0,3 тыс. т в 1962 г. до 2,0 тыс. т в 1970 г. (с 1,8 до 23,5 \% мирового производства). Поставки ниобиевого сырья в этот период из других стран (Нигерии, Заир-Конго, Австралии) не превышают 600 т/год.

В 1979-1995 гг. мировой уровень добычи ниобия составляет 10,5-16,2 тыс. т/год. Основная доля добычи ниобиевого сырья производится компанией CBMM на месторождении Араша (77,7-85,8 \% мирового производства). В Канаде остановка выработанного рудника Ока замещается вовлечением в эксплуатацию нового месторождения Ниобик (карбонатитовый массив Сент-Оноре) [13], разрабатываемого компанией Niobic Inc., поставляющей 1,9-3,3 тыс. т ниобия в год $(11,4-20,6 \%$ мирового производства). Из других стран (Заир-Конго, Австралии, Руанды) поставки ниобиевого сырья составляют до 660 т/год. 


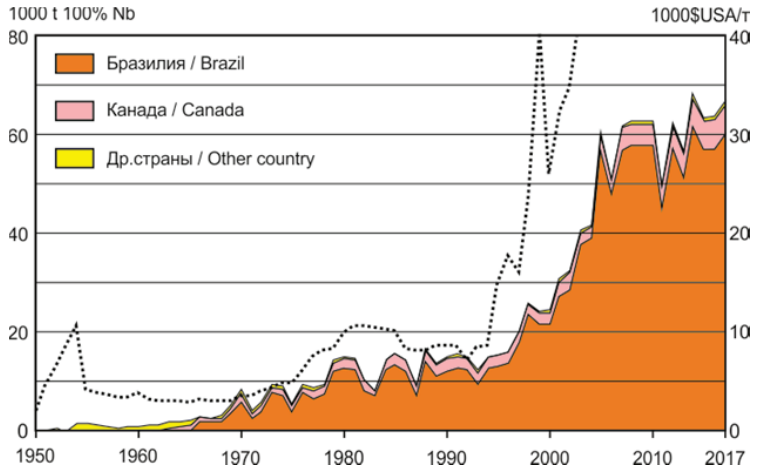

Pис. 2. Диналика мирового производства ниобиевого сырья (по странам - лидерам добычи) в пересчете на $100 \%$ Nb и ми ровых иен на него (по иенам импорта США) за 1950-2017 г2. Составлено по данным Геологической службы США [6] и Британии [7], информационного иенmpa TrendEconomy [10]

Fig. 2. Dynamics of global production of niobium raw materials (by the leading countries of production) in terms of $100 \% \mathrm{Nb}$ and world prices for it (at USA import prices ) for 1950-2017. Compiled according to the data of the U.S. Geological Survey [6] and Britain Geological Survey [7], Information Center TrendEconomy [10]

В 1996 г. начался интенсивный рост мирового спроса на ниобий с 16,2 тыс. т до максимума в 68,7 тыс. т $100 \%$ Nb в 2014 г. (темпы изменений $+7,3 \%$ ггод). Как и ранее, подавляющее количество ниобиевого сырья добывается в Бразилии, где кроме Араши компанией Mineracao Catalao de Goias S.A. начата эксплуатация карбонатитового месторождения ниобия Каталао [14]. Доля Бразилии в мировом производстве ниобия составляет 87,7-94,0 \% . В Канаде компания Niobic Inc. продолжает добычу ниобиевого сырья на одноименном месторождении - 2,3-5,9 тыс. т/год. Из других стран (Руанды, Конго, Нигерии) поставки ниобиевого сырья суммарно составляют до 875 т/год.

\section{Минералогические потоки товарных ниобиевых сырьевых продуктов}

В минералогическом отношении ниобиевые сырьевые продукты представлены пирохлоровым и колумбит-танталитовыми концентратами. Ввиду различий качества концентратов во времени динамика объемов их добычи и учтенного в концентрате ниобия конформны не полностью (рис. 2, 3). В 2007-2017 гг. мировая добыча пирохлорового кониентрата составляла 200-250 тыс. т/год или 98-99 \% от суммы ниобиевых концентратов. Подавляющее количество пирохлорового концентрата поступает с месторождений Араша и Каталао в Бразилии и Ниобек в Канаде. Объемы добычи колумбит-танталитовых кониентратов, получаемых при разработке существенно танталовых месторождений, незначительны и составляют 3-6 тыс. т/год. Начиная с 90-х гг. ХХ в. колумбиттанталитовые концентраты становятся базовым сырьем для производства тантала (увеличившего спрос на изготовление твердых конденсаторов в микроэлектронике), а ниобиевая продукция из них становится зависимым попутным компонентом. Колумбит-танталитовый концентрат поступает с разрабатываемых танталовых месторождений Гитарама (Руанда), Кисенго (Конго), Питинга (Бразилия), Тамбани (Малави), Кэтлин и Пилгангоора (Австралия), Тоуми (Бенин), Муиане (Мозамбик).

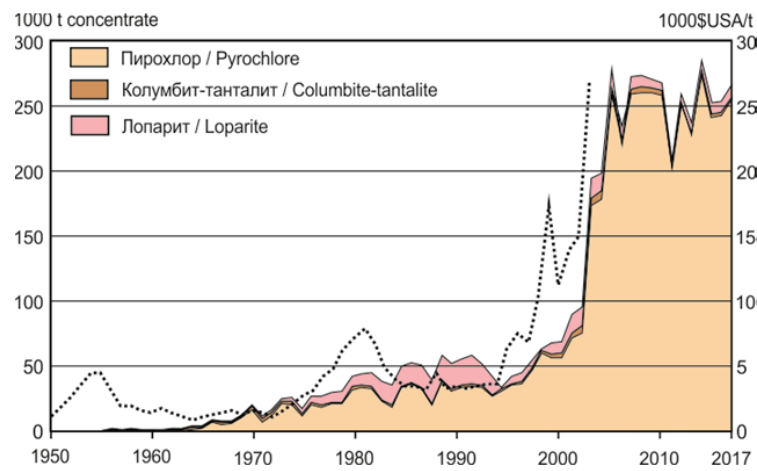

Pис. 3. Диналика мирового производства ниобиевых концентра тов (по минеральныл видам ) и мировых иен на пирохлорный концентрат (по иенам илпорта в США) за 1950-2017 г2. Составлено по данным Геологической службы США [6 ] и Британии [7], Госкомстата России [9] и Информационного иентра TrendEconomy [10]

Fig. 3. Dynamics of global production of niobium concentrates (by mineral species) and world prices for pyrochlor concentrate (at USA import prices) for 1950-2017. Compiled according to the data of the U.S. Geological Survey [6] and Britain Geological Survey [7], Federal State Statistics Service of Russia [9] and Information Center TrendEconomy [10]

В России ниобий извлекается как побочный продукт при переработке комплексного редкометально20 кониентрата лопарита, добываемого на Ловозерском редкоземельно-ниобиевом месторождении в Мурманской области. Максимальная добыча концентрата составляла до 25 тыс. т/год, но в 90 -х гг. $\mathrm{XX}$ в. она уменьшилась до 5,3-8,9 тыс. т/год. При переработке лопаритового концентрата на Соликамском магниевом заводе получают $1,9-3,1$ тыс. т/год редкоземельных продуктов, $0,6-2,2$ тыс. т/год титановой продукции, 27-49 т/год танталовых соединений и 397-628 т/год ниобиевых товарных продуктов [15]. Кроме этого, на Ключевском ферросплавном заводе из поставок российского сырья периодически осуществляется производство феррониобия (до 150 т/год) [16]. Национальное производство ниобиевого сырья в России исчезающе мало и обеспечивает всего 6-9 \% существующего потребления ниобиевых продуктов.

\section{Мировые ресурсы ниобия}

Как отмечалось выше, месторождения ниобия представляют собой геологически интересные объекты, зачастую с комплексом других ценных компонентов, таких как тантал, редкоземельные металлы, литий, цирконий, титан, фосфаты, плавиковый шпат. В результате к настоящему времени обнаружено и готово к эксплуатации множество месторождений ниобия в геологических ком- 
плексах магматических карбонатитов, редкометалльных пегматитов, щелочных гранитов и сиенитов. В таблице приводятся данные по крупнейшим в мире подготовленным ниобиевым месторождениям. В разработке находятся пирохлоровые месторождения в карбонатитах Араша и Каталао в Бразилии, а также Ниобек в Канаде. В не- больших объемах (первые сотни тонн в год) эксплуатируются пегматитовые месторождения колумбита-танталита в провинции Катанга (Демократическая Республика Конго) и области Гитарама в Руанде (рис. 4).

Крупнейшее в мире месторождение ниобия Араша в Бразилии (таблица, рис. 4) с годовой добы-

таблица. Крупнейшие в мире месторождения ниобия

Table. World's largest niobium deposits

\begin{tabular}{|c|c|c|c|c|}
\hline Месторождение/Mine & Страна/Country & $\begin{array}{l}\text { Геологический тип месторождения } \\
\text { Geological type of the deposit }\end{array}$ & $\begin{array}{c}\text { Peсурсы, тыс. т } \mathrm{Nb}_{2} \mathrm{O}_{5} \\
\text { Resources, } 1000 \mathrm{t} \mathrm{Nb}_{2} \mathrm{O}_{5}\end{array}$ & $\begin{array}{c}\text { Среднее содержание } \mathrm{Nb}_{2} \mathrm{O}_{5} \\
\text { в рудах, } \% \\
\text { Grade of } \mathrm{Nb}_{2} \mathrm{O}_{5}, \%\end{array}$ \\
\hline Араша/Araxa & Бразилия/Brazil & Карбонатиты/Carbonatite & 26498 & 1,89 \\
\hline Бонга/Bonga & Ангола/Angola & Карбонатиты/Carbonatite & 3955 & 0,48 \\
\hline Ниобек/Niobec & Канада/Canada & Карбонатиты/Carbonatite & 1760 & 0,42 \\
\hline Мотзфельд/Motzfeldt & Гренландия/Greenland & $\begin{array}{c}\text { Редкометалльные граниты и сиениты } \\
\text { Rare-metal granite and syenite } \\
\end{array}$ & 1564 & 0,46 \\
\hline Каталао/Catalão & Бразилия/Brazil & Карбонатиты/Carbonatite & 1317 & 1,24 \\
\hline Томторское/Tomtor & Россия/Russia & Карбонатиты/Carbonatite & 1219 & 3,99 \\
\hline Тхор-Лэйк/Thor Lake & Канада/Canada & $\begin{array}{c}\text { Редкометалльные граниты и сиениты } \\
\text { Rare-metal granite and syenite }\end{array}$ & 1123 & 0,36 \\
\hline Гхурауях/Ghurayyah & $\begin{array}{l}\text { Саудовская Аравия } \\
\text { Saudi Arabia }\end{array}$ & Карбонатиты/Carbonatite & 1093 & 0,28 \\
\hline Баян-Обо/Bayan Obo & Китай/China & $\begin{array}{c}\text { Редкометалльные граниты } \\
\text { Rare-metal granite }\end{array}$ & 1040 & 0,13 \\
\hline $\begin{array}{l}\text { Большезиминское } \\
\text { Bolsheziminskoe }\end{array}$ & Россия/Russia & Карбонатиты/Carbonatite & 750 & 1,50 \\
\hline Элк-Крик/Elk Creek & CШA/USA & Карбонатиты/Carbonatite & 654 & 0,64 \\
\hline Ловозерское/Lovozero & Россия/Russia & $\begin{array}{c}\text { Редкометалльные щелочные сиениты } \\
\text { Rare-metal alkaline syenite }\end{array}$ & 585 & 0,24 \\
\hline Сукулу/Sukulu & Уганда/Uganda & Карбонатиты/Carbonatite & 550 & 0,30 \\
\hline Катугинское/Katuginskoe & Россия/Russia & $\begin{array}{c}\text { Редкометалльные граниты и сиениты } \\
\text { Rare-metal granite and syenite }\end{array}$ & 472 & 0,31 \\
\hline
\end{tabular}

Источники: Геологическая служба США [6], Министерство природных ресурсов России [5], Информационно-аналитический центр «Минерал» [11].

Sources: U.S. Geological Survey [6], Ministry of Natural resources of Russia [5], Information and analytical center «Mineral» [11].

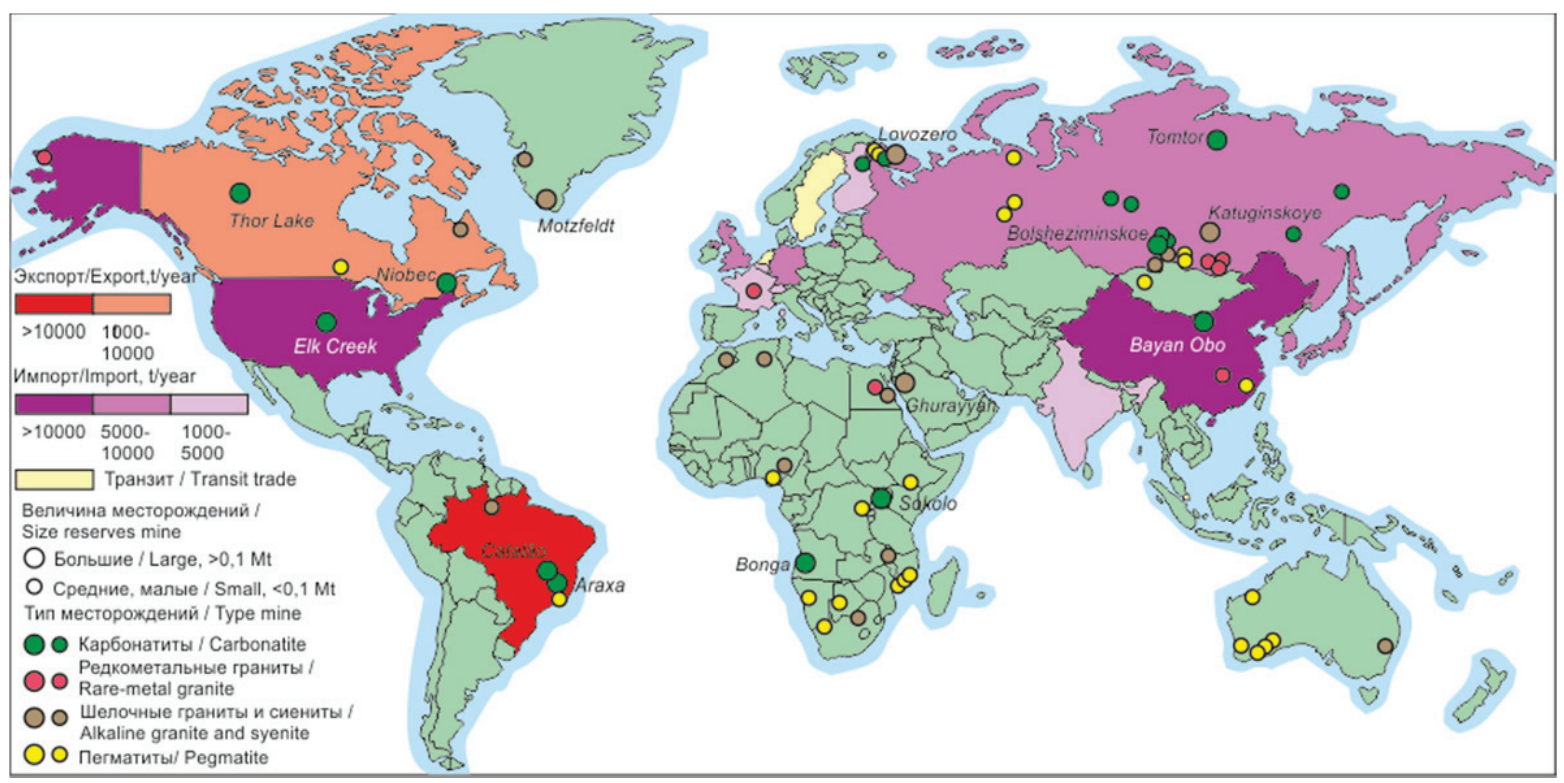

Pис. 4. Карта мира с локализаиией ниобиевых месторождений и стран-лидеров международной торговли феррониобием (экспортеры, импортеры и транзитеры)

Fig. 4. World map with locations of niobium mines and countries-leaders of international trade in ferroniobium (exporters, importers and transiters) 
чей в 10-х гг. XXI в. 41-58 тыс. т $100 \% \mathrm{Nb} /$ год включает 26,5 млн т $\mathrm{Nb}_{2} \mathrm{O}_{5}$ со средним содержанием $1,89 \% \mathrm{Nb}_{2} \mathrm{O}_{5}$, в т. ч. 11,4 млн т $\mathrm{Nb}_{2} \mathrm{O}_{5}$ со средним содержанием $2,48 \% \quad \mathrm{Nb}_{2} \mathrm{O}_{5}$ приходится на рыхлую кору выветривания, сформировавшую легкообогатимые руды со свободными зернами пирохлора. Огромные запасы, высокое природное качество руд, организованное производство, низкие издержки при добыче, обогащении и переработке пирохлорового концентрата на феррониобий позволяют компании Companhia Brazileira de Metalurgia e Mineraçã монопольно доминировать на мировом рынке ниобиевых продуктов [12]. Продолжается наращивание добычи ниобиевого сырья (2017 г. - 6 тыс. т в пересчете на $100 \%$ Nb) и на другом бразильском месторождении Каталао (разрабатываемое ныне компанией Anglo American Brazil Ltd.), оцениваемое в 1,3 млн т $\mathrm{Nb}_{2} \mathrm{O}_{5}$ при среднем содержании $1,24 \% \mathrm{Nb}_{2} \mathrm{O}_{5}$, в т. ч. на участке Каталао II - рыхлая кора выветривания, включающая 57 тыс. т $\mathrm{Nb}_{2} \mathrm{O}_{5}$ при среднем содержании $1,67 \% \quad \mathrm{Nb}_{2} \mathrm{O}_{5}$ [14]. Кроме вышеприведенных месторождений в Бразилии известны месторождения Талираи, Моно Дос Сьес Лагос, Питинга, МолтаГранде и другие.

Третье в мире по запасам и второе по объемам добычи карбонатитовое месторождение Ниобик в Канаде включает 1,76 млн т $\mathrm{Nb}_{2} \mathrm{O}_{5}$, при среднем содержании 0,42\% $\mathrm{Nb}_{2} \mathrm{O}_{5}$, и уровне добычи в 10-е гг. XXI в. 4,4-5,8 тыс. т $100 \%$ Nb/год. Не смотря на относительно низкое качество карбонатитовых руд и подземный способ добычи, компания Niobec Inc., имея устоявшееся производство феррониобия и ориентируясь на максимальные цены отгрузки бразильских ниобиевых продуктов, осуществляет стабильные поставки в США [13, 17]. В Канаде находится также крупное неразрабатываемое месторождение Тхор-Лэйк $\left(1,1\right.$ млн т $\mathrm{Nb}_{2} \mathrm{O}_{5}$ при среднем содержании $0,36 \% \mathrm{Nb}_{2} \mathrm{O}_{5}$ ), которое представляет собой геологический комплекс щелочных гранитов и сиенитов с минерализацией $\mathrm{Zr}, \mathrm{Nb}$ и редкоземельных элементов [18]. Кроме вышерасмотренных месторождений в Канаде известны месторождения Бин-Ривер, Кривейр, Стронг-Лейк, Ока и другие.

Все остальные крупнейшие месторождения мира ввиду многокомпонентности имеют высокие риски реализации проектов и поэтому для инвесторов малоинтересны. Второе в мире по учтенным запасам ниобиевое месторождение Бонга в Намибии (4,0 млн т $\mathrm{Nb}_{2} \mathrm{O}_{5}$ при среднем содержании 0,48 \% $\mathrm{Nb}_{2} \mathrm{O}_{5}$ ) находится в кальцитовых карбонатитах, обогащенных пирохлором, апатитом, магнетитом, флюоритом и минералами редкоземельных элементов [19]. В Гренландии располагается месторождение Мотзфельд $\left(1,6\right.$ млн т $\mathrm{Nb}_{2} \mathrm{O}_{5}$ при среднем содержании 0,46 \% $\mathrm{Nb}_{2} \mathrm{O}_{5}$ ), где в карбонатитах находится минерализация $\mathrm{Zr}$, $\mathrm{Ta}, \mathrm{Nb}$ и редкоземельных элементов [20]. Месторождение Гхурауях в Саудовской Аравии (1,1 млн т $\mathrm{Nb}_{2} \mathrm{O}_{5}$ при среднем содержании $0,28 \% \mathrm{Nb}_{2} \mathrm{O}_{5}$ ) представлено щелочными гранитами с Ta-Nb минерализацией [21]. Разрабатывае- мое редкоземельное месторождение Баян-Обо в $К$ maе в карбонатитах включает попутную ниобиевую минерализацию (1,0 млн т $\mathrm{Nb}_{2} \mathrm{O}_{5}$ при среднем содержании $0,1 \% \mathrm{Nb}_{2} \mathrm{O}_{5}$ ), но извлечения ниобиевого сырья не производится [22]. Месторождение ЭлкКрик в США (0,7 млн т $\mathrm{Nb}_{2} \mathrm{O}_{5}$ при среднем содержании 0,64\% $\mathrm{Nb}_{2} \mathrm{O}_{5}$ ) представляет собой рыхлую кору выветривания карбонатитового массива, обогащенную гематитом, баритом и пирохлором и перекрытую толщей (180 м) более молодых пород, что делает это месторождение гранично рентабельным [23]. Редкоземельно-апатитовое месторождение Сукулу с попутной ниобиевой минерализацией в одноименном карбонатитовом массиве в Уганде также проблемно по перспективам его освоения $(0,55$ млн т $\mathrm{Nb}_{2} \mathrm{O}_{5}$ при среднем содержании 0,3\% $\mathrm{Nb}_{2} \mathrm{O}_{5}$ ). В $\mathrm{As}$ стралии до 2008 г. разрабатывалось олово-танталовое пегматитовое месторождение Гринбушес (Западная Австралия) с попутным извлечением колумбит-танталитового концентрата, но в настоящее время оно законсервировано. Остановлена работа и на других австралийских ниобий-танталовых месторождениях - Вуджин, Кабот, Ялго.

В России разрабатывается Ловозерское редкоземельное месторождение, где ниобий является попутным компонентом в перерабатываемом лопаритовом концентрате. Запасы ниобия в этом месторождении составляют 0,6 млн т $\mathrm{Nb}_{2} \mathrm{O}_{5}$ при среднем содержании 0,24\% $\mathrm{Nb}_{2} \mathrm{O}_{5}$ ), но объемы реализации извлекаемого ниобия полностью зависят от технологической цепочки переработки лопаритового концентрата на базовый товарный продукт - губчатый титан. При этом ниобий и оксиды редких земель, которые являются лишь попутными продуктами, и объемы их реализации зачастую не увязываются по объемам со спросом потребителей этих товарных продуктов. Разрабатывались также мелкие пегматитовые месторождения Вишневогорское и Липовый Лог на Среднем Урале с выпуском пирохлорового концентрата, а также многокомпонентные месторождения в редкометалльных гранитах (Орловское, Етыкинское и Завитинское в Забайкалье) с извлечением попутного колумбит-танталитового концентрата, но эти производства были закрыты в 1990-е гг. как нерентабельные.

Другие известные в России ниобиевые месторождения представлены многокомпонентными объектами, требующими комплексного извлечения полезных ископаемых и компонентов, имеющих различную конъюнктуру и объемы сбыта, что повышаете риски их освоения.

Катугинское месторождение в щелочных породах в Забайкальском крае с запасами 0,47 млн т $\mathrm{Nb}_{2} \mathrm{O}_{5}$ со средним содержанием $\mathrm{Nb}_{2} \mathrm{O}_{5}$ в рудах 0,31\% включает редкоземельную ( $\Sigma \mathrm{TR}-0,25 \%)$, циркониевую $\left(\mathrm{ZrO}_{2}-1,38\right.$ \% ) и криолитовую минерализацию, что затрудняет его комплексное освоение [5].

В Иркутской области находится Nb-TR-фосфатное месторождение Белозиминское, представляющее собой литофицированную кору выветривания 
по карбонатитам с ресурсами 0,75 млн т $\mathrm{Nb}_{2} \mathrm{O}_{5}$ со средним содержанием $1,5 \% \mathrm{Nb}_{2} \mathrm{O}_{5}$ [24].

Наиболее перспективным считается Томторское месторождение в Республике Саха-Якутия с редкоземельно-редкометальной минерализацией в карбонатитах с ресурсами 1,2 млн т $\mathrm{Nb}_{2} \mathrm{O}_{5}$ при среднем содержании $3,99 \% \mathrm{Nb}_{2} \mathrm{O}_{5}$. В его пределах выделяется супербогатый участок Буранный, включающий $8 \%$ ресурсов месторождения со средним содержанием $6,7 \% \mathrm{Nb}_{2} \mathrm{O}_{5}$ и $9,3 \% \mathrm{TR}_{2} \mathrm{O}_{3}$ [5]. Однако кроме технологических сложностей от многокомпонентности руд для этого месторождения серьезным препятствием является крайняя сложность транспортной доступности.

Кроме вышеприведенных подготовленных ниобиевых объектов в России известны и другие ниобиевые месторождения - в карбонатитах: Чуктуконское, Татарское (Красноярский край), Арбарастах, Горноозерское (Республика Саха-Якутия), Среднезиминское, Большетагнинское (Иркутская область), Неске-Вара (Мурманская область), в щелочных гранитах и сиенитах: Улуг-Танзегское (Республика Тыва), Зашихинское (Иркутская область), Тайкеу, Лонгот-Юган и Усть-Мраморное (Ямало-Ненецкий округ), в пегматитах: Вишняковское, Гольцовое (Иркутская область), Колмозерсклое, Ролмостундровское (Мурманская область) [25-27].

Суммарные ресурсы ниобиевого сырья в мире превышают 44 млн т $\mathrm{Nb}_{2} \mathrm{O}_{5}$, что достаточно для обеспечения мировой потребности в ниобиевых продуктах с учетом увеличения $+10 \% /$ год более чем на 50 лет. Распределение запасов ниобия по странам (рис. 5), в принципе, повторяет последовательность национальной принадлежности крупнейших месторождений мира. Ожидаемо на Бразилию приходится $63 \%$ мировых ресурсов ниобиевого сырья.

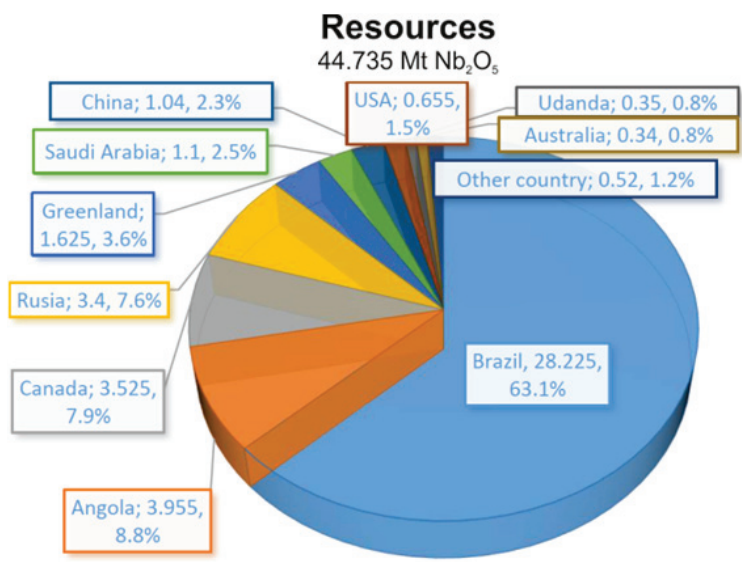

Pис.5. Мировые ресурсы ниобиевого сырья по состоянию на 2015 2., в пересчете на $\mathrm{Nb}_{2} \mathrm{O}_{5}$. Составлено с уточненияли по данным Геологической службы США [6] и Инфорла иионного иентра «Минерал-Инфо» [11]

Fig. 5. World resources of niobium raw materials as of 2015, in terms of $\mathrm{Nb}_{2} \mathrm{O}_{5}$. Compiled with clarifications according to the U.S. Geological Survey [6] and Information Center "Mineral-Info» [11]

\section{Феррониобий}

До 1960 г. свыше 70 \% мирового производства передельных ниобиевых продуктов (93\% - феррониобий, $5 \%$ - ниобий металлический, $2 \%$ карбид ниобия), которые использовались в основном в производстве жаропрочных сталей для нужд атомной промышленности, приходится на США (до 1,5 тыс. т/год). К 1965 г. доля импорта ниобиевых концентратов в США снизилась до $40 \%$ от их мирового производства и появились новые производители конечных ниобиевых продуктов. В 1964 г. начато производство феррониобия из собственного сырья в Канаде, в 1965 г. - в Бразилии. Развилась и международная торговля феррониобием, в которой в качестве продавцов участвуют его производители - Бразилия, Канада и Австрия, а в качестве покупателей США, Япония, Франция и Бельгия. В 1970-е гг. главные мировые производители ниобиевого сырья - Бразилия и Канада - практически полностью перешли на реализацию продукции более высокого передела - феррониобия. С 1970-х гг. в СССР производилось до 2 тыс. т ниобиевых продуктов, получаемых при переработке лопаритового концентрата, но в 1990-х гг. их предложение упало до 0,5 тыс. т/год.

На рис. 6, а показана динамика мирового производства феррониобия за 1975-2017 гг., отражающая доминирующую роль предложения бразильских производителей в это время. Суммарное потребление феррониобия определяется его спросом в производстве специальных сталей. Поэтому динамика мирового производства феррониобия в первом приближении повторяет динамику выпуска стальной продукции, которая осложняется тенденцией неравномерного увеличения во времени удельного потребления феррониобия в промышленно развитых странах. В 1980-1993 гг. мировое производство и сбыт феррониобия находился на уровне 20-24 тыс. т/год с локальными провалами до 12-15 тыс. т/год в 1983 и 1987 гг. С 1994 г. вследствие бурного развития производства стали в Китае наметился подъем общемирового потребления феррониобия плоть до 41-42 тыс. т/год в 2001-2004 гг. (прирост $+7,1 \% /$ год). В 2005 г. ввиду увеличения объемов производства специальных сталей в промышленно развитых странах процесс роста объемов потребления феррониобия также ускорился, достигнув максимума в 105 тыс. т в 2014 г. (прирост в 2005-2014 гг. +13,1\%/год). Финансовый кризис 2008 г. сопровождался временной просадкой производства феррониобия в 2009 г. на $-38 \%$.

Производство феррониобия в Бразилии в 2010-2017 гг. составляло 77-88 тыс. т/год, в Канаде - 7,2-9,2 тыс. т/год, в других странах 80-450 т/год (суммарно).

Доля Бразилии в мировом производстве феррониобия выросла с $58 \%$ в 1977 г. до 90-92\% в 10-х гг. XXI в. (рис. 6, b). Доля Канады, наоборот, уменьшилась за этот период с 20-24 до 7-9\%. Производство феррониобия в других странах, составлявшее в 1970 -е гг. до 20 \%, к 1995 г. сократилось до исчезающе малых долей (менее 1 \%). 

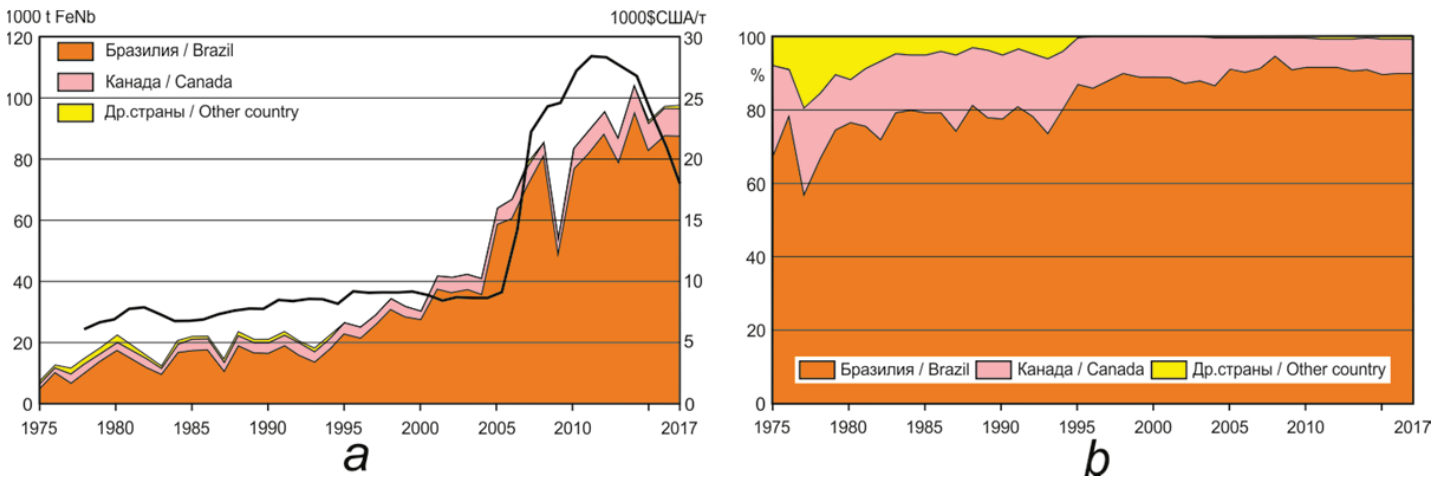

Pис.6. Диналика мирового производства феррониобия по странал-лидерам производства ( $а$ - в тысячах тонн, $b$ - в процентах от мирового производства) и мировых иен на феррониобий (по иенам его илпорта в США) за 1975-2017 г2. Составлено по данныл Геологической службы США [6] и Британии [7], Информационного иентра TrendEconomy [10]

Fig. 6. Dynamics of ferroniobium world production by leading countries ( $a$ - in thousands of tons, $b$ - as a percentage of world production) and world prices for ferroniobium (at prices of its imports in the United States) for 1975-2017. Compiled according the data of the U.S. Geological Survey [6] and Britain Geological Survey [7], Information Center TrendEconomy [10]

В международной торговле находится свыше $95 \%$ от производимого в мире феррониобия. На экспорт Бразилия и Канада поставляет феррониобий за вычетом объемов национального потребления черной металлургии. Динамика экспорта феррониобия из этих двух стран полностью конформна динамике их национальных производств ферросплава (рис. 6,7$)$. Темпы прироста объемов мировой торговли (экспорта/импорта) феррониобия за 1996-2017 гг. составили +8,7 \% /год. В 2010-2017 гг. экспорт из Бразилии составлял $69,5-86,6$ тыс. т/год, из Канады 6,1-10,7 тыс. т/год (рис. 7). В 1998-2001 гг. имели место реэкспортные потоки до 10,3 тыс. т/год феррониобия в Нидерландах, а в 2014-2017 гг. - в Сингапуре (до 10,6 тыс. т/год), свойственные этим странам, специализирующимся на встречной импортно-экспортной торговле [24]. Доля реэкспорта от импорта феррониобия в этих странах составляет 80-100 и 90-100 \%, соответственно. Высокая доля реэкспорта отмечается в Швеции в 2014-2017 гг. - 50-65 \%. Годовая маржа от разницы импортных и экспортных цен в периоды реэкспорта составляет для Нидерландов $+17 \ldots 36 \%$ от стоимости транзитных объемов феррониобия, $+7 \ldots 13 \%$ - для Сингапура и $+3 . . .5 \%$ - для Швеции. Очевидно, что для Швеции факт высокой доли реэкспорта не имеет спекулятивной составляющей. Повышенная доля реэкспорта (более $25 \%$ ) наблюдается во Франции, Словакии и Чехии.

Феррониобий, импортируют ведущие промышленные страны, производящие стальную продукцию: США, Япония, Германия, Китай, Южная Корея, Италия, Бельгия, Франция, Россия и другие страны (рис. 8). Начиная с 1999 г. появился и весьма значительно вырос импорт феррониобия в Китай (до 16,8 тыс. т в 2017 г.). Растет импорт феррониобия в США (до 11,5 тыс. т/год), Россию (до 5,2 тыс. т/год) и Южную Корею (до 3,6 тыс. т/год), сокращается - в Испанию. Как и для случаев реэкспорта феррониобия имели место транзитные потоки импорта в 1998-2001 гг. до 7,9 тыс. т/год фер- рониобия в Нидерландах, а в 2014-2017 гг. в Сингапуре - до 11,6 тыс. т/год.

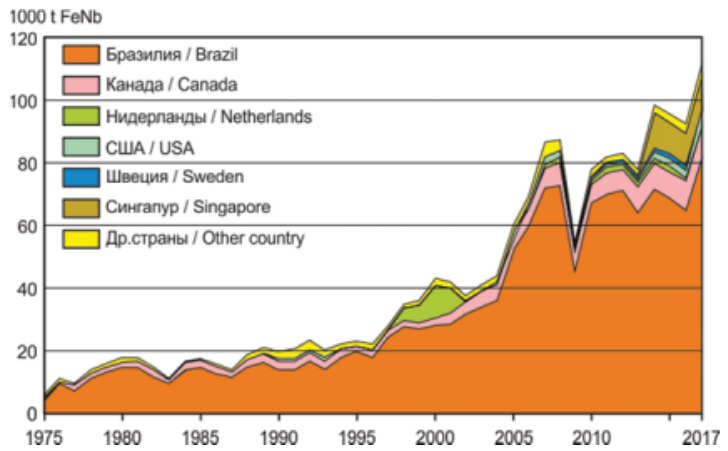

Pис. 7. Диналика мирового экспорта феррониобия за 1975-2017 г2. Составлено по данным Геологической службы США [6 ] и Британии [7], Информационного центра TrendEconoту [10]

Fig. 7. Dynamics of world exports of ferroniobium for 1975-2017. Compiled according to the data of the U.S. Geological Survey [6] and Britain Geological Survey [7], Information Center TrendEconomy [10]

$1000 \mathrm{t}$ FeNb

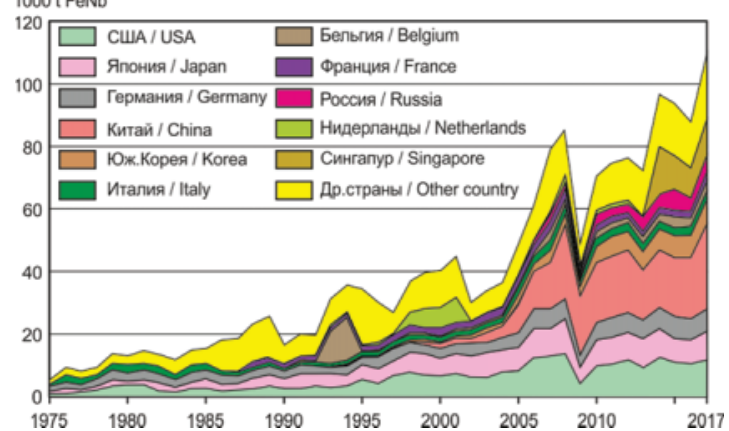

Рис. 8. Диналика мирового илпорта феррониобия (по странамлидерали илпорта) за 1975-2017 г2. Составлено по данным Геологической службы США [6] и Британии [7], Инфорлационного иентра [10]

Fig. 8. Dynamics of world import of ferroniobium for 1975-2017. Compiled according to the data of the U.S. Geological Survey [6] and Britain Geological Survey [7], Information Center TrendEconomy [10] 
Цены на феррониобий в 1960-1990 гг., в принципе, были конформны ценам на ниобиевый концентрат [13]. Но уже в 1980-х гг. их ценообразование стало непрозрачным, когда с 1981 г. бразильские производители, а в 1989 г. и канадские, перестали публиковать данные реальных цен отгрузки.

На рис. 9 приводится динамика экспортных цен стран-производителей феррониобия и средней цены мировой торговли этим товарным продуктом. Среднемировая цена феррониобия, в принципе, совпадает с конфигурацией изменений экспортной цены товарных поставок из Бразилии, охватывающих свыше 80 \% мировой торговли этим товаром. В 2002-2006 гг. цены находились на стабильном уровне - 8,6-9,8 \$США/кг, но на этапе предкризисного «перегрева» мировой экономики, в 2007 г., начался значительный рост цен феррониобия вплоть до 26,3 \$ США/кг в 2012 г. (темпы изменения $+19,8 \%$ /год). Следует отметить отсутствие провала цены на феррониобий в кризисном 2009 г., который имел место для большинства сырьевых товарных продуктов. Это еще раз подтверждает высокую монополизацию мирового рынка феррониобия со стороны компании Companhia Brazileira de Metalurgia e Mineraçã, поставляющей на рынок 88-92 \% производимого в мире феррониобия. В 10-е гг. XXI в. на фоне последствий мирового экономического кризиса цены на феррониобий начали снижаться вплоть до 19,6 \$ США/кг в 2017 г. (темпы изменения $-5,7 \%$ /год).

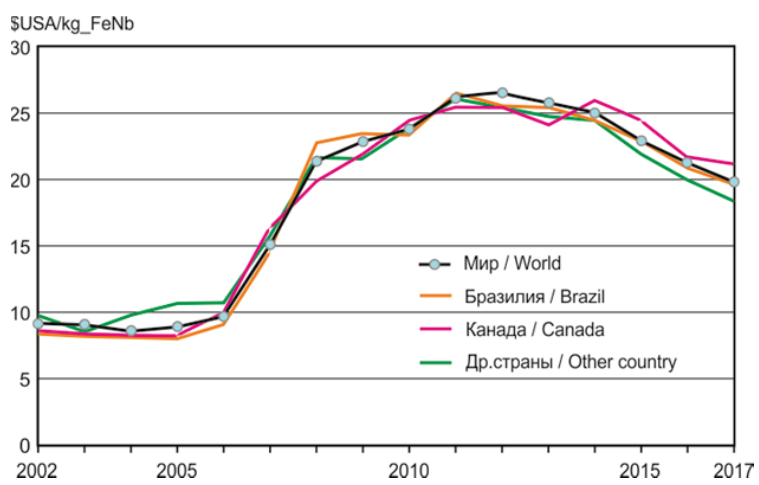

Рис.9. Динамика иен экспорта феррониобия по странал-лиде рам международной торговли за 2002-2017 г2. Составлено по данным Геологической службы США [6] и Брита нии [7], Федеральной таможенной службы России [8] и Информационного иентра TrendEconomy [10]

Fig. 9. Dynamics of ferroniobium export prices of by countries-leaders of international trade for 2002-2017. Compiled according to the data of the U.S. Geological Survey [6] and Britain Geological Survey [7], Federal Customs Service of Russia [8] and Information Center TrendEconomy [10]

На рис. 10 показана динамика цена импорта по странам-лидерам покупки феррониобия. Средние цены импорта ниже среднемировой наблюдаются лишь для Китая $(-1,5 \%$ отн.) и России $(-19,5 \%$ отн.). Большие ценовые скидки для России обусловлены ценовым маневром бразильских поставщиков на возможность появления российских конкурентов. Выше среднемировой цены феррониобия средние цены на импорт в Японию ( $+0,6 \%$ отн.), Францию $(+1,2 \%$ отн.), Италию $(+2,8 \%$ отн.), Бельгию $(+3 \%$ отн.), США (+3,8\% отн.), Германию $(+4,6 \%$ отн.), Британию (+6,2\% отн). Значительно выше среднемировых цены импорта феррониобия в Индию. Они составляли в 2006-2017 гг. $+39 . .65 \%$ отн. (в среднем $+48 \%$ отн.), что свидетельствует о высокой марже посредников на фоне бурного роста индийского потребления этого продукта в этом периоде с сотен тонн в год до 3,8 тыс. т в 2017 г.

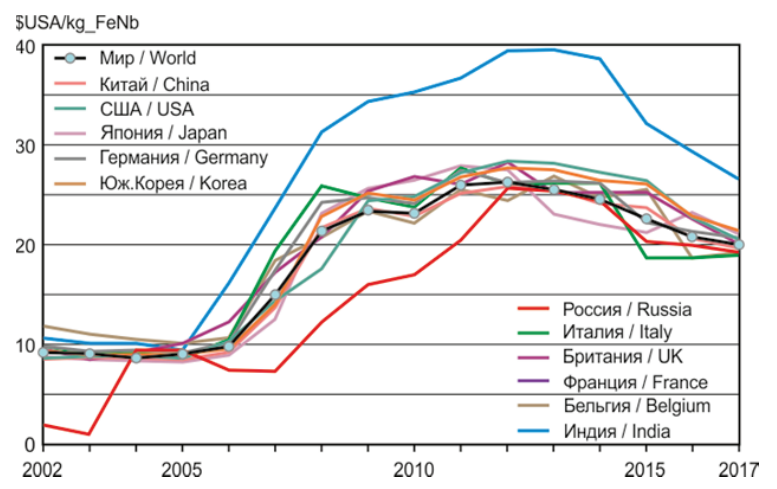

Рис. 10. Диналика иен илпорта феррониобия по странал-лидерал международной торговли за 2002-2017 г2. Составлено по данныл Геологической службы США [6] и Британии [7], Федеральной таможенной службы России [8] и Информационного иентра TrendEconomy [10]

Fig. 10. Dynamics of ferroniobium import prices by countries-leaders of international trade for 2002-2017. Compiled according to the data of the U.S. Geological Survey [6] and Britain Geological Survey [7], Federal Customs Service of Russia [8] and Information Center TrendEconomy [10]

Ценовый маневр монополии СВММ для российских потребителей произошел в начале XXI в. В 1999 г. главным потребителем феррониобия в России - ПАО «Северсталь» - было создано дочернее предприятие «Стальмаг» по добыче пирохлоровых концентратов из коры выветривания на Татарском карбонатитовом массиве в Красноярском крае с их поставкой на Ключевский завод ферросплавов [27]. Уже в 2000 г. из полученного концентрата было произведено 74 т феррониобия. Но после резкого снижения к 2001 гг. договорных отпускных цен для российских потребителей на бразильский феррониобий компании CBMM с 6,7-9,8 до 1,5-2,0 \$ США/кг данное производство стало нерентабельно и добыча на Татарском месторождении была законсервирована [16]. В 2004 г. цены предложения бразильского феррониобия вернулись на уровень мировых. В 2006-2011 гг., на фоне роста мировых цен на феррониобий, цены импорта поставок этого продукта из Бразилии в Россию были снижены на $-21 . .56 \%$ отн. от среднемировых - возможно, именно из-за опасений осуществления новых инвестиционных проектов на российских месторождениях ниобия. В дальнейшем (начиная с 2012 г.) на фоне снижения среднемировых цен феррониобия российские импортные цены опять приблизились к среднемировым $(-1 . .5 \%$ отн). 


\section{Мировое потребление ниобиевых продуктов}

Мировое потребление основного ниобиевого продукта - феррониобия - во времени увеличивается, имея прирост объемов $+9,1 \%$ /год, что значительно опережает прирост потребления стали $(+4,3 \%$ /год) и других ферросплавов $(+3 . . .6 \%$ /год). Соответственно растет мировое удельное потребление феррониобия на 1 т стальной продукции - с 28 г/т в 1996 г. до 63 г/т в 2017 г. (рис. 11).

В динамике абсолютного и удельного потребления феррониобия по странам мы имеем разные стартовые условия в начале анализируемого периода времени, разные темпы изменений, что осложняет сравнение эффективности использования этого ферросплава в национальных производствах стали.

По абсолютным объемам потребления феррониобия наибольшие темпы прироста приходятся на Kumaŭ - с 0,9 тыс. т в 1999 г. до 16,8 тыс. т в 2017 г. (темп прироста +25,2 \%/год). Высокие темпы прироста абсолютного потребления у Южной Кореи - с 0,4 тыс. т в 1996 г. до 7,2 тыс. т в 2017 г. (+17,6 \% /год), России - с 0,2 до 5,3 тыс. т (+17,4 \% /год), Индии - с 0 до 3,8 (+25,3 \% /год) и Бельгии - с 0,7 до 2,5 тыс. т (+14,5\% \% год).

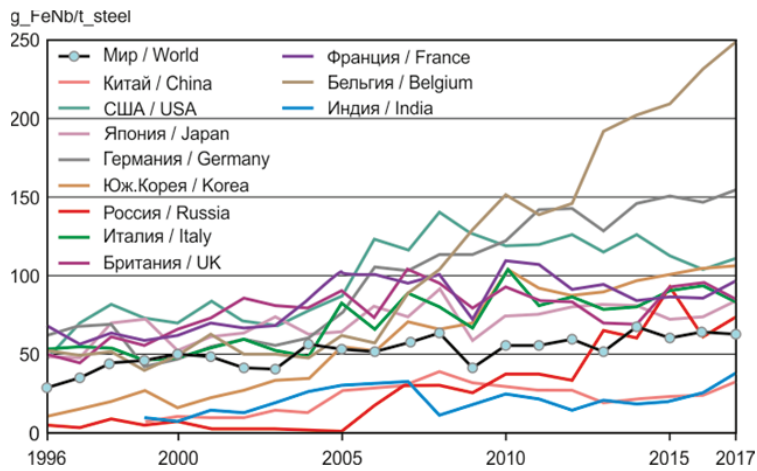

Рис. 11. Удельное потребление феррониобия при выплавке стали в иелом по миру и странам-лидерам его потребления за 1996-2017 г2. Составлено по данным Геологической службы США [6] и Британии [7], Информационного цен mpa TrendEconomy [10]

Fig. 11. Specific consumption of ferroniobium in steel production in the whole world and the countries-leaders of its consumption for 1996-2017. Compiled according to the data of the U.S Geological Survey [6] and Britain Geological Survey [7], In formation Center TrendEconomy [10]

Рецессивный (замедленный) темп прироста абсолютного потребления феррониобия (менее среднемирового уровня - +9,1% /год) наблюдается для Германии $(+7,1 \% /$ год), Италии $(6,1 \% /$ год $)$, США (+5,5 \% /год), Японии (+5,3\% \% /год), Франции $(+3,6 \%$ /год) и Британии $(+0,1 \% /$ год).

Превышается среднемировой уровень удельного потребления феррониобия (63 г $\mathrm{FeNb}$ на 1 т стали в 2017 г.) в Бельгии - $(250$ г/т), Герлании $(155$ г/т), США (111 г/т), Южной Корее $(106$ г/т), Франиии (97 г/т), Японии (85 г/т), Италии $(84$ г/т), Британии $(84$ г/т) и России $(73$ г/т). Ниже среднемирового уровень удельного потребле- ния феррониобия у стран с максимальными темпами прироста абсолютного потребления этого ферросплава - Китая $(32$ г/т) и Индии $(38$ г/т). Наибольшие темпы роста удельного потребления феррониобия наблюдаются в Бельгии с 40-60 г/т в 1990-е гг. до 250 г/т в 2017 г. (+14,5\% \% /год). При имеющихся темпах прироста эти страны выйдут на уровень удельного потребления феррониобия в 60-70 г/т к 2025-2028 гг.

\section{Возможности создания новых производств феррониобия}

Монополия рынка ниобиевых продуктов компанией CВMМ увеличивает ценовые риски торговли феррониобием, которые уже проявились в резком росте цен на этот продукт в 2007-2012 гг., опережающем темпы роста цен других сырьевых товарных продуктов, в т. ч. прочих ферросплавов и стали.

Отлаженное добывающее производство на крупнейшем в мире месторождении ниобия Араша с высококачественными и технологичными рыхлыми пирохлоровыми рудами позволяет компании CВMМ поддерживать низкий уровень издержек и маневрировать ценами, в том числе и противодействовать конкурентам, как в ситуации с проектом добычи ниобиевого сырья ПАО «Северсталь» в 2001-2003 гг. Поэтому, несмотря на наличие многих подготовленных к эксплуатации месторождений, проекты их освоения рассматриваются инвесторами как высокорисковые.

Наиболее значимой проблемой освоения большинства ниобиевых месторождений является многокомпонентность их состава. Месторождения Элк-Крик в США, Бонга в Намибии, Мотзфельд в Гренландии, Гхурауях в Саудовской Аравии, Баян-Обо в Китае, Сукулу в Уганде, Томторское и Белозиминское и Катугинское в России включают в составе руд кроме ниобиевого сырья также циркониевые и редкоземельные минералы, фосфаты, флюорит, барит и другие потенциально товарные продукты. Комплексная разработка многокомпонентных руд несет риски дисбаланса реализации получаемых товарных продуктов, как на примере разработки Ловозерского редкометального месторождения, а также танталовых месторождений с попутной ниобиевой минерализацией.

Первый фактор новых ниобиевых проектов наличие спроса и необходимости обеспечения национальной сырьевой безопасности. Учитывая относительно небольшие объемы национального потребления большинства стран-потребителей (первые тысячи тон в год) новые ниобиевые проекты должны ориентироваться, кроме обеспечения национального спроса, на занятие доли мирового рынка, контролируемого в настоящее время бразильской компанией Companhia Brazileira de Metalurgia e Mineraçã. Минимальный объем годовой добычи должен превышать 10 тыс. т (по примеру устойчивой работы канадской компании Niobic Inc.). Такие объемы можно достигнуть только на крупных месторождениях. 
Второй фактор - наличие финансовых ресурсов для обеспечения таких крупных инвестиционных проектов.

Третий фактор - технологические сложности переработки ниобиевых руд, зачастую многокомпонентных.

Из состоятельных стран-потребителей ниобиевых продуктов, имеющих на своей территории крупные месторождения, только США, Саудовская Аравия и Россия при определенных условиях могут осуществить национальные проекты добычи ниобиевого сырья.

Гранично рентабельное месторождение ЭлкКрик в США может быть освоено при применении к нему налоговых льгот и преференций, подобных применяемым к отрасли добычи сланцевой нефти и газа. В этом случае оно может стать привлекательным инвестиционным проектом для собственных и иностранных инвесторов.

Месторождение Гхурауях в Саудовской Аравии может стать целевым инвестиционным проектом диверсификации государственных вложений с весьма больших доходов нефтяной отрасли, наподобие практики уже осуществленных проектов развития национальных металлургической и химической отраслей промышленности.

На территории Китая (мировой лидер потребления ниобиевых продуктов) пока не обнаружено крупных месторождений ниобия с высоким качеством руд. Поэтому вероятно целевое формирование устойчивого импортного потока ниобиевого сырья путем прямых инвестиций в один из проектов разработки крупных зарубежных месторождений: Бонга в Намибии, Сукулу в Уганде, Мотзфельд в Гренландии, Больщезиминское в России. Учитывая развитие геополитических интересов Китая более вероятны африканские проекты (по аналогии с южносуданскими нефтяными проектами китайских инвестиций).

В России компанией «Восток Инжиниринг» (дочернее предприятие Госкорпорации «Ростех» и группы компаний «ИСТ») подготавливается к освоению Томторское ниобий-редкоземельное месторождение в Республике Саха-Якутия [28, 29]. Самые серьезные проблемы - удаленность месторождения, расположенного в Заполярье, от транспортной инфраструктуры и многокомпонентность рудных образований, с потребностью максимально полного извлечения. Но в проекте его освоение упор делается на базовую роль при добыче выпуска редкоземельных элементов из коллективного фосфор-ниобий редкоземельного концентрата [30, 31], что само по себе является сложной технологической задачей разделения индивидуальных редкоземельных продуктов (металлов, оксидов, оксалатов). Ниобиевая продукция при этом может оказаться зависимой от планирования объемов выпуска редкоземельной продукции. Наиболее предпочтительна была бы организация селективного обогащения добываемых руд с получением раздельных пирохлоровых и фосфат-редкоземельных концен- тратов с планированием объемов добычи и переработки руды исходя из максимально потребных объемов одного из этих двух товарных продуктов со временным складированием избыточного второго концентрата. Эта схема переработки руд позволила бы максимально насытить национальный спрос одновременно и ниобиевыми и редкоземельными продуктами. Уровень годовой добычи 100 тыс. т руды на Томторском месторождении позволил бы выпуск до 10 тыс. т феррониобия и до 2 тыс. т редкоземельных продуктов (со складированием $70 \%$ добытого фосфат-редкоземельного концентрата), что обеспечило бы перекрытие национальной потребности в этих продуктах.

\section{Выводы}

1. Мировой рынок ниобиевых продуктов, выросший за последние 25 лет в 4,3 раза (до 68,7 тыс. т $\mathrm{Nb}_{2} \mathrm{O}_{5}$ в 2014 г.), характеризуется абсолютным доминированием бразильской компании Companhia Brazileira de Metalurgia e Mineraçã (CBMM), осуществившей $86 \%$ мирового накопленного производства ниобиевого сырья. Разработка крупнейшего в мире месторождения ниобия Араша с высококачественными и технологичными пирохлоровыми рудами (среднее содержание $\mathrm{Nb}_{2} \mathrm{O}_{5} 1,89 \%$ ) в коре выветривания карбонатитов и отлаженное производство с добычей до 54 тыс. т $\mathrm{Nb}_{2} \mathrm{O}_{5} /$ год позволяют CВММ удерживать монопольную позицию, препятствуя входу на рынок ниобия новых участников.

2. Мировая добыча пирохлорового концентрата в 10-е гг. XXI в. составляет 200-250 тыс. т/год, или 98-99 \% , от суммы ниобиевых концентратов. Объемы добычи колумбит-танталитовых концентратов, получаемых при разработке существенно танталовых месторождений, составляют 3-6 тыс. т/год. Добыча лопаритового концентрата, содержащего ниобий, составляет 5-9 тыс. т/год.

3. Учтенных мировых ресурсов ниобия $(44,7$ млн т $\mathrm{Nb}_{2} \mathrm{O}_{5}$ ) достаточно более чем на 50 лет растущего потребления ниобиевых продуктов. $63 \%$ мировых ресурсов ниобия приходится на Бразилию, где кроме Араши известны месторождения кор выветривания карбонатитов Каталао, Талираи, Моно-Дос-Сьес-Лагос, Питинга, Молта-Гранде. В Канаде кроме Ниобека известны месторождения в карбонатитах (Кривейр) и редкометалльных гранитах (Тхор-Лэйк, БлюРивер и Стронг-Лейк). Крупные карбонатитовые месторождения ниобия с высокой степенью изученности известны в США (Элк-Крик), Анголе (Бонга), Уганде (Сукулу) и России (Томторское Большезиминское), а крупные ниобиевые месторождения в щелочных гранитах и сиенитах - в Саудовской Аравии (Гхурауях), Гренландии (Мотзфельд), Китае (Баян-Обо) и России (Ловозерское и Катугинское).

4. Динамика мирового производства феррониобия в первом приближении повторяет динамику вы- 
пуска стальной продукции, которая осложняется тенденцией неравномерного увеличения во времени удельного потребления феррониобия в промышленно развитых странах. Сбыт феррониобия вырос с 20-24 тыс. т/год в 1990-е гг. до 105 тыс. т в 2014 г. - темпы прироста за 1996-2017 гг. составили +8,7 \% /год. Доля Бразилии в мировом производстве феррониобия выросла с 58 \% в 1977 г. до 90-92\% в 10-х гг. XXI в., а доля Канады, наоборот, уменьшилась за этот период с 20-24 до 7-9 \%. Производство феррониобия в других странах, составлявшее в 1970-е гг. до 20 \% , к 1995 г. сократилось до исчезающе малых долей (менее 1 \%)

5. В международной торговле находится более $95 \%$ от производимого в мире феррониобия. На экспорт Бразилия поставляет 69,5-86,6 тыс. т/год, Канада - 6,1-10,7 тыс. т/год. Имеют место реэкспортные потоки до 10,3 тыс. т/год феррониобия в Нидерландах, до 10,6 тыс. т/год в Сингапуре, а также в Швеции, Франции, Словакии, Чехии.

6. Главными импортерами феррониобия являются: США, Япония, Германия, Китай, Южная Корея, Италия, Бельгия, Франция и Россия. Выросли объемы импорта феррониобия в Китай (до 16,8 тыс. т в 2017 г., прирост $+20,0 \%$ /год), в США (до 11,5 тыс. т/год), Россию (до 5,2 тыс. т/год) и Южную Корею (до 3,6 тыс. т/год), сократились в Испанию.

7. Среднемировая цена феррониобия в 2002-2006 гг. находилась на стабильном уровне 8,6-9,8 \$ США/кг, на этапе предкризисного «перегрева» мировой экономики, в 2007 г., начался ее значительный рост - вплоть до 26,3 \$ США/кг в 2012 г. (темпы изменения $+19,8$ \% /год), а в период же рецессии цены на феррониобий начали снижаться вплоть до 19,6 \$ США/кг в 2017 г. (темпы изменения $-5,7$ \% /год). Средние цены импорта ниже среднемировой наблюдаются лишь для Китая $(-1,5 \%$ отн.) и России $(-19,5 \%$ отн.). Низкие цены феррониобия для России появились в результате ценового маневра компании СBMM, препятствующей развитию российских проектов добычи ниобиевого сырья. Выше среднемировой цены феррониобия средние цены на импорт в Японию $(+0,6 \%$ отн. $)$, Францию $(+1,2 \%$ отн.), Италию (+2,8 \% отн.), Бельгию

\section{СПИСОК ЛИТЕРАТУРЫ}

1. Минеральное сырье. Ниобий и тантал. Справочник / В.С. Кудрин, Ю.С. Кушпаренко, Н.В. Петрова и др. - М.: Геоинформмарк, 1998. -82 c.

2. Use of Niobium High Strength Steels with 450 MPA Yield Strength for Construction / L. Silvestre, P. Langenberg, T. Amaral et al. // HSLA Steels 2015, Microalloying 2015 and Offshore Engineering Steels 2015 Conference Proceedings. - 6 November 2015. - P. 931-939. DOI: 10.1002/9781119223399.ch116.

3. Critical Mineral Resources of the United States - Economic and Environmental Geology and Prospects for Future Supply.
(+3\% отн.), США (+3,8 \% отн.), Германию $(+4,6 \%$ отн.), Британию (+6,2 \% отн). Значительно выше среднемировых цены импорта феррониобия в Индию, составлявшие в 2006-2017 гг. $+39 . .65 \%$ отн.

8. Мировое потребление основного ниобиевого продукта - феррониобия - во времени увеличивается, имея прирост объемов $+9,1 \%$ /год, что значительно опережает прирост потребления стали $(+4,3 \% /$ год) и других ферросплавов $(+3 . .6 \%$ \% год). Соответственно растет мировое удельное потребление феррониобия на 1 т стальной продукции - с 28 г/т в 1996 г. до 63 г/т в 2017 г. По абсолютным объемам потребления феррониобия наибольшие темпы прироста приходятся на Китай - с 0,9 тыс. т в 1999 г. до 16,8 тыс. т в 2017 г. (темп прироста +25,2% /год). Высокие темпы прироста абсолютного потребления у Южной Кореи (+17,6 \% /год), России $(+17,4$ \% /год), Индии $(+25,3 \% /$ год) и Бельгии $(+14,5 \% /$ год). Превышается среднемировой уровень удельного потребления феррониобия в Бельгии $(250$ г/т), Германии (155 г/т), США (111 г/т), Южной Кореи (106 г/т), Франции (97 г/т), Японии (85 г/т), Италии $(84$ г/т), Британии $(84$ г/т) и России $(73$ г/т).

9. Компания СВММ ведет активную ценовую политику, препятствующую появлению в других странах новых проектов добычи ниобия. Еще одной проблемой освоения большинства ниобиевых месторождений является многокомпонентность их состава, которая несет риски дисбаланса реализации получаемых товарных продуктов. Поэтому в качестве новых сырьевых ниобиевых проектов предпочтительны монопродуктовые пирохлоровые месторождения. Из состоятельных стран-потребителей ниобиевых продуктов, имеющих на своей территории крупные месторождения, только США, Саудовская Аравия и Россия при определенных условиях могут осуществить национальные проекты добычи ниобиевого сырья. Наиболее интересен проект разработки Томторского ниобийредкоземельного месторождения в России, при определенных условиях возможно осуществление проектов Элк-Крик в США, Гхурауях в Саудовской Аравии, Бонга в Намибии, Сукулу в Уганде, Мотзфельд в Гренландии, Большезиминское в России.

U.S. Geological Survey / K.J. Schulz, J.H. DeYoung, R.R. Seal, D.C. Bradley. - Reston, Virginia: 2017. - 862 p. URL: https:// pubs.er.usgs.gov/publication/pp1802 (дата обращения: 15.04.2019).

4. Study on the review of the list of Critical Raw Materials. Critical Raw Materials Factsheets. Deloitte Sustainability; British Geological Survey; Bureau de Recherches Géologiques et Minières; Netherlands Organisation for Applied Scientific Research. 2017. - 515 p. URL: https://publications.europa.eu/en/publication-detail/-/publication/7345e3e8-98fc-11e7-b92d01aa75ed71a1/language-en (дата обращения: 15.04.2019). 
5. Государственный доклад «0 состоянии и использовании минерально-сырьевых ресурсов Российской Федерации в 2016-2017 годах». - M.: MПР, 2018. - 370 c. URL: http:// www.mnr.gov.ru/docs/o_sostoyanii_i_ispolzovanii_mineralno_syrevykh_resursov_rossiyskoy_federatsii/gosudarstvennyy_doklad_o_sostoyanii_i_ispolzovanii_mineralno_syrevykh_resursov_rossiyskoy_federatsii/ (дата обращения 15.04.2019).

6. Геологическая служба CШA (U.S. Geological Survey). URL: http://minerals.usgs.gov/minerals/pubs/commodity/tin/index.html\#mcs (дата обращения 15.04.2019).

7. Геологическая служба Британии (Britain Geological Survey). URL: http://www.bgs.ac.uk/mineralsuk/statistics/worldStatistics.html (дата обращения 15.04.2019).

8. Федеральная таможенная служба России. URL: http://stat. customs.ru/analytics/ (дата обращения: 15.04.2019).

9. Федеральная служба государственной статистики России. URL: https://fedstat.ru/indicator/57783 (дата обращения: 15.10.2019).

10. Международная торговля товарами. TrendEconomy. URL: http://data.trendeconomy.ru/ (дата обращения 15.04.2019).

11. Информационно-аналитический центр «Минерал-Инфо». URL: http://www.mineral.ru/Center/index.html (дата обращения 10.05.2018).

12. Paraiso-Fo 0.D.S., Fuccio R., Betz E.W. Mining, ore preparation and niobium-based materials production at Araxá, Brazil // High Temperature Materials and Processes. - 1993. - V. 11. № 1-4. - P. 119-138. DOI: 10.1515/HTMP.1993.11.1-4.119.

13. Dufresne C., Goyette G. The production of ferroniobium at the Niobec mine // Niobium, Science and Technology: Proceedings of the International Symposium Niobium 2001. - Orlando, FL, United States. 2001. - Code 62351. - P. 29-35.

14. The Catalão I niobium deposit, Central Brazil: Resources, geology and pyrochlore chemistry / P.F.D.0. Cordeiro, J.A. Brod, M. Palmieri et al. // Ore Geology Reviews. - 2011. - V. 41. - № 1. P. 112-121. DOI: 10.1016/j.oregeorev.2011.06.013.

15. Соликамский магниевый завод. Годовой отчет $0 \mathrm{A0}$ «Соликамский магниевый завод» за 2017 год. - Соликамск: ОА0 «СМЗ», 2018. - 91 c. URL: http://см3.pф/raport/2018/itog2017/godovoj_otchet_smz_2017_final_dlja_sajta.pdf (дата обращения: $15.04 .2019)$

16. Боярко Г.Ю., Хатьков В.Ю. Добыча ниобия в России // Известия Томского политехнического университета. - 2004. T. 307. - № 1. - C. 149-153.

17. Sutton J.A. Columbium and tantalum // Minerals yearbook metals, minerals, and fuels 1971. U.S. Geological Survey. - 1971. P. 449-459. URL: http://images.library.wisc.edu/EcoNatRes/EFacs2/MineralsYearBk/MinYB1971v1/reference/econatres.minyb1971v1.jsutton.pdf (дата обращения: 15.04.2019).

18. Controls on the concentration of zirconium, niobium, and the rare earth elements in the Thor Lake rare metal deposit, Northwest Territories, Canada / E.R. Sheard, A.E. Williams-Jones, M. Hei- ligmann, C. Pederson, D.L. Trueman // Economic Geology. 2012. - V. 107. - № 1. - P. 81-104. DOI: 10.2113/econgeo.107.1.81.

19. Geology, geochemistry and genesis of the Bonga carbonatite-type niobium deposit, Angola / Y. Zhang, X. Gu, Y. Peng, L. Zheng, Y. Zhang, H. Gao, S. Dong // Earth Science Frontiers. - 2014. V. 21. - № 5. - P. 50-68. D0I: 10.13745/j.esf.2014.05.006.

20. Steenfelt A. High-technology metals in alkaline and carbonatitic rocks in Greenland: recognition and exploration // Journal of Geochemical Exploration. - 1991. - V. 40. - № 1-3. - P. 263-279. DOI: $10.1016 / 0375-6742(91) 90042-\mathrm{S}$.

21. Küster D. Granitoid-hosted Ta mineralization in the Arabian-Nubian Shield: Ore deposit types, tectono-metallogenetic setting and petrogenetic framework // Ore Geology Reviews. - 2009. V. 35. - № 1. - P. 68-86. D0I: 10.1016/j.oregeorev.2008.09.008.

22. Genesis of the Bayan Obo Fe-REE-Nb formation in Inner Mongolia, North China Craton: a perspective review / X. Yang, X. Lai, F. Pirajno, Y. Liu, L. Mingxing, W. Sun // Precambrian Research. - 2017. - V. 288. - P. 39-71. DOI: 10.1016/j.precamres.2016.11.008.

23. Carlson M.P., Treves S.B. The Elk Creek carbonatite, Southeast Nebraska - an overview // Natural Resources Research. - 2005. V. 14. - № 1. - P. 39-45. DOI: 10.1007/s11053-005-4677-x.

24. Хатьков В.Ю., Боярко Г.Ю. Мировые и российские встречные импортно-экспортные потоки минерального сырья // Известия Томского политехнического университета. Инжиниринг георесурсов. - 2018. - Т. 329. - № 3. - С. 145-167.

25 Елютин А.В., Чистов Л.Б., Эпштейн Е.М. Проблемы освоения минерально-сырьевой базы ниобия // Минеральные ресурсы России. Экономика и управление. - 1999. - № 3. - С. 22-29.

26 Ниобий России: состояние, перспективы освоения и развития минерально-сырьевой базы / Е.М. Эпштейн, Т.Ю. Усова, Н.А. Данильченко и др. // Минеральное сырье. Серия геологоэкономическая. -2000 . - № 8. -103 с.

27. Семененко Ю. Российский ниобий. Первая ласточка из Сибири // Природно-ресурсные ведомости, 31 августа 2001 г.

28. Создание в Сибири технологической платформы по добыче и переработке редкоземельных металлов (дискуссия) / 3.3. Умаров, М.А. Ягольницер, А.В. Толстов и др. // ЭКО. - 2012. № 11. - C. $38-49$.

29. Боярко Г.Ю., Хатьков В.Ю. Торговля индивидуальными редкоземельными товарными продуктами на российском рынке // Цветные металлы. - 2017. - № 7. - С. 7-13.

30. Томтор как приоритетный инвестиционный проект обеспечения России собственным источником редкоземельных элементов / Н.П. Похиленко, В.А. Крюков, А.В. Толстов, Н.Ю. Самсонов // ЭКО. - 2014. - № 2 (476). - С. 22-35.

31. Толстов А.В., Самсонов Н.Ю. Томтор: геология, технологии, экономика // ЭКО. - 2014. - № 2 (476). - С. 36-44.

Поступила 16.09.2019 2.

\section{Информация об авторах}

Боярко Г.Ю., доктор экономических наук, кандидат геолого-минералогических наук, профессор отделения нефтегазового дела Инженерной школы природных ресурсов НИУ Томский политехнический университет. 
UDC 339.13:546.882

\title{
DYNAMICS OF GLOBAL PRODUCTION AND COMMODITY FLOWS OF NIOBIUM RAW MATERIALS
}

\author{
Grigory Yu. Boyarko, \\ gub@tpu.ru \\ National Research Tomsk Polytechnic University, \\ 30, Lenin Avenue, Tomsk, 634050, Russia.
}

\begin{abstract}
The relevance of the work is caused by the need to study the problems of the monopoly in the niobium world market.
The aim of this research is to study the dynamics of world commodity flows (production, import, export, consumption) of niobium products (niobium concentrates and ferroniobium); to develop proposals to reduce the level of monopolization of the supply of niobium raw materials.

Methods: statistical, graphic, logical.

Results. The world market of niobium products is exclusively monopolized with absolute domination of the Brazilian company Companhia Brazileira de Metalurgia e Mineraçã (CBMM). Development of the world's largest niobium Arash Deposit with high-quality and technological pyrochlore ores and well-established production allows CBMM to hold a monopoly position. The world's recorded niobium resources $\left(44,7\right.$ million tonnes $\left.\mathrm{Nb}_{2} \mathrm{O}_{5}\right)$ are sufficient for more than 50 years of growing consumption of niobium products. Brazil accounts for $63 \%$ of the world's niobium resources. World sales of ferroniobium increased from 25 thousand tons in 1996 to 105 thousand tons in 2014, growth rate $+8,7 \%$ /year. More than $95 \%$ of the world's ferroniobium is traded internationally. Brazil exports 69,5-86,6 thousand tons/year, Canada- 6,1 to 10,7 thousand tons/year. The main importers of ferroniobium are the USA, Japan, Germany, China, South Korea, Italy, Belgium, France and Russia. Imports of ferroniobium increased in China (up to 16,8 thousand tons in 2017, an increase of $+20,0 \%$ / year), in the United States, Russia and South Korea, decreased - in Spain. Average price of ferroniobium in time grew from 8,6 US \$/kg in 2004 to 26,3 US \$/kg in 2012, and then started to decline up to 19,6 US \$/kg in 2017. Average import prices below the world average are observed for China (-1,5\% rel.) and Russia (-19,5\% rel.). Average import prices of ferroniobium $(+0,6 \ldots 6,2 \%$ rel.) to Japan, France, Italy, Belgium, USA, Germany, Britain are above the world one. Average import prices of ferroniobium to India are significantly higher than the world one. In 2006-2017 they were +39...65\% rel. Ferroniobium world consumption grows over time. Its increase is of $+9,1 \% /$ year, that exceeds significantly the increase of production of steel $(+4,3 \% /$ year) and other ferroalloys (+3...6\% /year). Global specific consumption of ferroniobium per 1 ton of steel products is growing - from $28 \mathrm{~g} / \mathrm{t}$ in 1996 to $63 \mathrm{~g} / \mathrm{t}$ in 2017. In terms of absolute volumes of ferroniobium consumption, the highest growth rates are in China - from 0,9 thousand tons in 1999 to 16,8 thousand tons in 2017 (growth rate +25,2\%/year). South Korea, Russia, India and Belgium have high absolute consumption growth rates as well. Ferroniobium consumption (2017) in Belgium (250 g/t), Germany (155 g/t), USA (111 g/t), South Korea $(106 \mathrm{~g} / \mathrm{t})$, France $(97 \mathrm{~g} / \mathrm{t})$, Japan $(85 \mathrm{~g} / \mathrm{t})$, Italy $(84 \mathrm{~g} / \mathrm{t})$, Britain $(84 \mathrm{~g} / \mathrm{t})$ and Russia $(73 \mathrm{~g} / \mathrm{t})$ exceeds the world average level of specific consumption of ferroniobium. CBMM has the active pricing policy that prevents the emergence of new niobium mining projects in other countries. The second problem of development of the most part of niobium deposits is the complexity of their composition, which bears the risk of imbalance in implementation of the resulting commercial products. The most interesting project of the development of Tomtor niobium-rare-earth deposits in Russia, under certain conditions it is possible to implement projects elk Creek in United States, Ghurabah in Saudi Arabia, Bonga in Namibia, Sukulu in Uganda, Motzfeldt in Greenland, Bolshezemelskoe in Russia.
\end{abstract}

\section{Key words:}

Niobium raw materials, Brazil, monopoly, ferroniobium, production, export, import, consumption, pricing.

\section{REFERENCES}

1. Kudrin V.S., Kushparenko Yu.S., Petrova N.V. Mineralnoe syrye. Nioby i tanyal. Spravochnik [Mineral raw material. Niobium and tantalum. Handbook]. Moscow, Geoinformmark Publ., 1998. $82 \mathrm{p}$.

2. Silvestre L., Langenberg P., Amaral T. Use of Niobium High Strength Steels with 450 MPA Yield Strength for Construction. HSLA Steels 2015, Microalloying 2015 and Offshore Engineering Steels 2015 Conference Proceedings. 6 November 2015. pp. 931-939. DOI: 10.1002/9781119223399.ch116.

3. Schulz K.J., DeYoung J.H., Seal R.R., Bradley D.C. Critical Mineral Resources of the United States - Economic and Environmental Geology and Prospects for Future Supply. U.S. Geological Survey. Reston, Virginia, 2017. 862 p. Available at: https:// pubs.er.usgs.gov/publication/pp1802 (accessed 15 May 2019).

4. Study on the review of the list of Critical Raw Materials. Critical Raw Materials Factsheets. Deloitte Sustainability. British Geological Survey. Bureau de Recherches Géologiques et Minières; Netherlands Organisation for Applied Scientific Research. 2017. 515 p. Available at: https://publications.europa.eu/en/publication-detail/-/publication/7345e3e8-98fc-11e7-b92d01aa75ed71a1/language-en (accessed 15 May 2019).

5. Gosudarstvenny doklad «0 sostoyanii i ispolzovanii mineralno-syryeoykh resursov Rossiyskoy Federatsii v 2016-2017» [State re- port « $0 \mathrm{n}$ the state and use of mineral resources of the Russian Federation in 2016-2017»]. 2018. Available at: http://www.mnr. gov.ru/docs/o_sostoyanii_i_ispolzovanii_mineralno_syrevykh_resursov_rossiyskoy_federatsii/gosudarstvennyy_doklad_o_sostoyanii_i_ispolzovanii_mineralno_syrevykh_resursov_rossiyskoy_federatsii/ (accessed 15 May 2019).

6. U.S. Geological Survey (USGS). Available at: http://minerals.usgs.gov/minerals/pubs/commodity/tin/index.html\#mcs (accessed 15 May 2019).

7. British Geological Survey (BGS). Available at: http://www. bgs.ac.uk/mineralsuk/statistics/worldStatistics.html (accessed 15 May 2019).

8. Federalnaya tamozhennaya sluzhba Rossii [Federal Customs Service of Russia]. Available at: http://stat.customs.ru/analytics/ (accessed 15 May 2019).

9. Federalnaya sluzhba gosudarstvennoy statistiki Rossii [Federal State Statistics Service of Russia]. Available at: https://fedstat.ru/indicator/57783 (accessed 10 October 2019).

10. TrendEconomy. Available at: http://data.trendeconomy.ru/dataviewer/trade/statistics/ (accessed 15 May 2019).

11. Mineral-Info. Information and Analytical Center. Available at: http://data.trendeconomy.ru/ (accessed 15 May 2019).

12. Paraiso-Fo 0.D.S., Fuccio R., Betz E.W. Mining, ore preparation and niobium-based materials production at Araxá, Brazil. High 
Temperature Materials and Processes, 1993, vol. 11, no. 1-4, pp. 119-138. D0I: 10.1515/HTMP.1993.11.1-4.119.

13. Dufresne C., Goyette G. The production of ferroniobium at the Niobec mine. Niobium, Science and Technology. Proceedings of the International Symposium. Orlando, FL, United States. 2001. Code 62351. pp. 29-35.

14. Cordeiro P.F.D.0., Brod J.A., Palmieri M. The Catalão I niobium deposit, Central Brazil: Resources, geology and pyrochlore chemistry. Ore Geology Reviews, 2011, vol. 41, no. 1, pp. 112-121. D0I: $10.1016 /$ j.oregeorev.2011.06.013.

15. Solikamskiy magnievy zavod [Annual report of «Solikamsk magnesium plant» for 2017]. Solikamsk, SMZ Publ., 2018. 91 p. Available at: http://cm3.pd/raport/2018/itog2017/godovoj otchet_smz_2017_final_dlja_sajta.pdf (accessed 15 May 2019).

16. Boyarko G.Y Yu., Khatkov V.Yu. Niobium mining in Russia. Bulletin of the Tomsk Polytechnic University, 2004, vol. 307, no. 1, pp. 149-153. In Rus.

17. Sutton J.A. Columbium and tantalum. Minerals yearbook metals, minerals, and fuels 1971. U.S. Geological Survey. 1971. pp. 449-459. Available at: http://images.library.wisc.edu/EcoNatRes/EFacs2/MineralsYearBk/MinYB1971v1/reference/econatres.minyb1971v1.jsutton.pdf (accessed 15 May 2019).

18. Sheard E.R., Williams-Jones A.E., Heiligmann M., Pederson C., Trueman D.L. Controls on the concentration of zirconium, niobium, and the rare earth elements in the Thor Lake rare metal deposit, Northwest Territories, Canada. Economic Geology, 2012, vol. 107, no. 1, pp. 81-104. D0I: 10.2113/econgeo.107.1.81.

19. Zhang Y., Gu X., Peng Y., Zheng L., Zhang Y., Gao H., Dong S. Geology, geochemistry and genesis of the Bonga carbonatite-type niobium deposit, Angola. Earth Science Frontiers, 2014, vol. 21, no. 5, pp. 50-68. DOI: 10.13745/j.esf.2014.05.006.

20. Steenfelt A. High-technology metals in alkaline and carbonatitic rocks in Greenland: recognition and exploration. Journal of $\mathrm{Ge}$ ochemical Exploration, 1991, vol. 40, no. 1-3, pp. 263-279. DOI: 10.1016/0375-6742(91)90042-S.

21. Küster D. Granitoid-hosted Ta mineralization in the Arabian-Nubian Shield: Ore deposit types, tectono-metallogenetic setting and petrogenetic framework. Ore Geology Reviews, 2009, vol. 35, no. 1, pp. 68-86. DOI: 10.1016/j.oregeorev.2008.09.008.
22. Yang X., Lai X., Pirajno F., Liu Y., Mingxing L., Sun W. Genesis of the Bayan Obo Fe-REE-Nb formation in Inner Mongolia, North China Craton: a perspective review. Precambrian Research, 2017, vol. 288, pp. 39-71. DOI: 10.1016/j.precamres.2016.11.008.

23. Carlson M.P., Treves S.B. The Elk Creek carbonatite, Southeast Nebraska - an overview. Natural Resources Research, 2005, vol. 14, no. 1, pp. 39-45. DOI: 10.1007/s11053-005-4677-x.

24. Khatkov V.Yu., Boyarko G.Yu. World and Russian counter import-export flows of mineral products. Bulletin of the Tomsk Polytechnic University. Geo assets Engineering, 2018, vol. 329, no. 3, pp. 145-167. In Rus.

25. Elyutin A.V., Chistov L.B., Epshtejn E.M. Problems of development of mineral resources base of niobium. Mineral resources of Russia. Economics \& management, 1999, no 3, 3p. 22-29. In Rus.

26 Epshtejn E.M., Usova T.Yu., Danilchenko N.A. Niobiy Rossii: sostoyanie, perspektivy osvoeniya i razvitiya mineralno-syrevoy bazy [Niobium of Russia: status, prospects of exploration and development of mineral resources]. Moscow, VIMS Publ., 2000. 103 p.

27. Semenenko Yu. Rossiysky nioby. Pervaya lastochka iz Sibiri [Russian niobium. The first swallow from Siberia]. Prirodo-resursnye vedomosti. August 31, 2001.

28. Umarov Z.Z., Yagolnitser M.A., Tolstov A.V. Creation of a technological platform for extraction and processing of rare earth metals in Siberia (discussion). ECO, 2012, no. 11, pp. 38-49. In Rus.

29. Boyarko G.Yu., Khatkov V.Yu. Trading of individual rare-earth marketable products on the Russian Market. Non-ferrous metals, 2017, no. 7, pp. 7-13. In Rus.

30. Pokhilenko N.P., Kryukov V.A., Tolstov A.V., Samsonov N.Yu. Tomtor as a priority investment project to provide Russia with its own source of rare earth elements. ECO, 2014, no. 2 (476), pp. 22-35. In Rus.

31. Tolstov A.V., Samsonov N.Yu. Tomtor: geology, technology, economics. ECO, 2014, no. 2 (476), pp. 36-44. In Rus.

Received: 16 September 2019.

\section{Information about the authors}

Grigory Yu. Boyarko, cand. Sc., Dr. Sc., professor, National Research Tomsk Polytechnic University. 